\title{
Constructing New Meanings of Chinese Architectural Heritage in the World Heritage Sites of Malacca Straits
}

\author{
Qing Mei \\ College of Architecture and Urban Planning, Tongji University, Shanghai, China
}

\begin{abstract}
This paper aims to construct new meanings of Chinese architectural heritage in the World Heritage sites of Malacca and Penang in the Malacca Straits. Inscribed in 2008, both sites have a history of more than 600 years of migrating trades and cultural exchanges with China. The influence of Chinese culture has given them diverse urban and architectural assets as tangible heritage, and different life styles of different groups of people as intangible heritage. Starting with a survey of the varied Chinese architectural heritage in the two World Heritage sites of the Malacca Straits, this study presents Chinese temples, huiguans, and shop-houses in the surviving historic city centres where various cultures and religions met and coexisted. These sites bear testimony to a living multi-cultural heritage and the tradition of Malay Archipelago, historic China and India, and modern Europe up to nowadays. Setting the two Wold Heritage sites in the full context of China, India and Southeast Asia which were part of the Maritime Silk Roads in ancient times, the study establishes a broader view to understand heritage as a cultural entity, explores the Chinese contribution to heritage, and calls for awareness towards heritage renovation and adaptive reuse throughout history. Furthermore, through an investigation of the architectural and cultural heritage in Southeast Asia from the $15^{\text {th }}$ to the $19^{\text {th }}$ century, the study intends to achieve a better understanding of the vernacular architecture and craftsmanship in southern China and the vernacular Chinese culture and art in Southeast Asia. It means to explore how Chinese cultural heritage was transplanted to the non-Chinese contexts in the Malacca Straits
\end{abstract}

KEYWORDS Malacca, Penang, Chinese architectural heritage, temple, huiguan, shop-house

\section{Introduction}

This article aims to present a historical and chronological picture of Chinese relationships with the Malacca Straits by reviewing the history of overseas Chinese who, in the early Ming dynasty, left for Nanyang. ${ }^{1}$ Furthermore, it seeks to provide a geographical and cultural context of Malacca and Penang as world heritage sites for Chinese temple, huiguan and shop-house architectural studies. The exploration covers the development of temple, huiguan and shop-house in Malacca and Penang from the mid- $17^{\text {th }}$ century to the mid- $19^{\text {th }}$ century. Throughout this period, many Chinese temples, huiguans and shop-houses were built, from the earliest Chinese temple Cheng Hoon Teng in Malacca, to the later Chinese temple Guang Fu Gong in Penang. These buildings profoundly shaped Chinese settlements in the Malacca Straits (Figure 1).

In the cases of temples, huiguans, shop-houses as well as other types of buildings and settlements, some buildings were rebuilt and renovated because of the structural limitations of the historical architecture; the wooden structure of many historic buildings couldn't withstand long-term storms and stress. Other buildings were demolished out of war and ignorance. A historical interpretative method is used to describe and analyse Chinese architectural phenomena based on historic literature, archives, site visits, investigations, photographs and measured drawings, as well as interviews with local scholars, builders, clients and their descendants in Malacca and Penang. In such a way, the study aims to develop a broader view of understanding heritage as a cultural entity, explore the meaning of the Chinese contribution to the heritage in these two world heritage sites, and to become aware of its renovation and adaptive reuse.

Some cultural geographers have suggested that Southeast Asia, in a certain point of view, is an area that is composed of multiple races, ${ }^{2}$ cultures or sub-cultures, where 


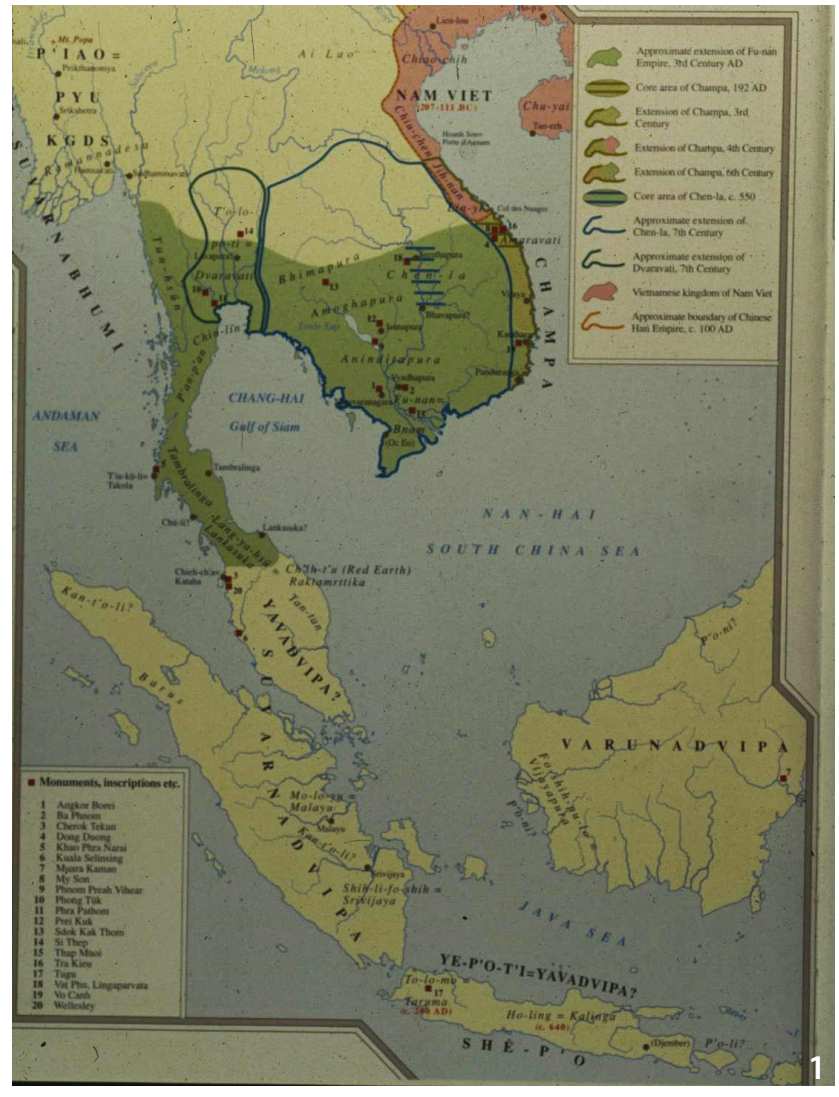

Figure 1 Map of Malacca Straits in Southeast Asia (Source: the author). Figure 2 Cheng Hoon Teng temple in Malacca (Source: the author). Figure 3 Guang Fu Gong temple in Penang (Source: the author).

immigrants who hold their cultural traditions often mix theirs with that of the different races. Within this regional context, Nanyang Chinese distinguish their settlements and buildings with distinctive characteristics of communities and organisations. They established their identity by clan, dialect and territory that showed adaptations to the new context. From an anthropological sense, temples and huiguans are shaped not only by materials and tools, but also by ideas and values rooted in cultural context. The cultural influences and the conventional rules and customs may even prove to be more influential; they shape the buildings and maintain their identities in a multi-cultural context. ${ }^{3}$ Moreover, they maintain the sense of 'belonging' to certain communities with commonly seen and accepted symbols when the natural, geographical context becomes totally different. Therefore, Cheng Hoon Teng in Malacca and Guang Fu Gong in Penang were selected as examples set within different urban contexts. Influenced by social, political, juridical and economic aspects, these temples could be better understood regarding their cultural meanings (Figure 2, Figure 3).
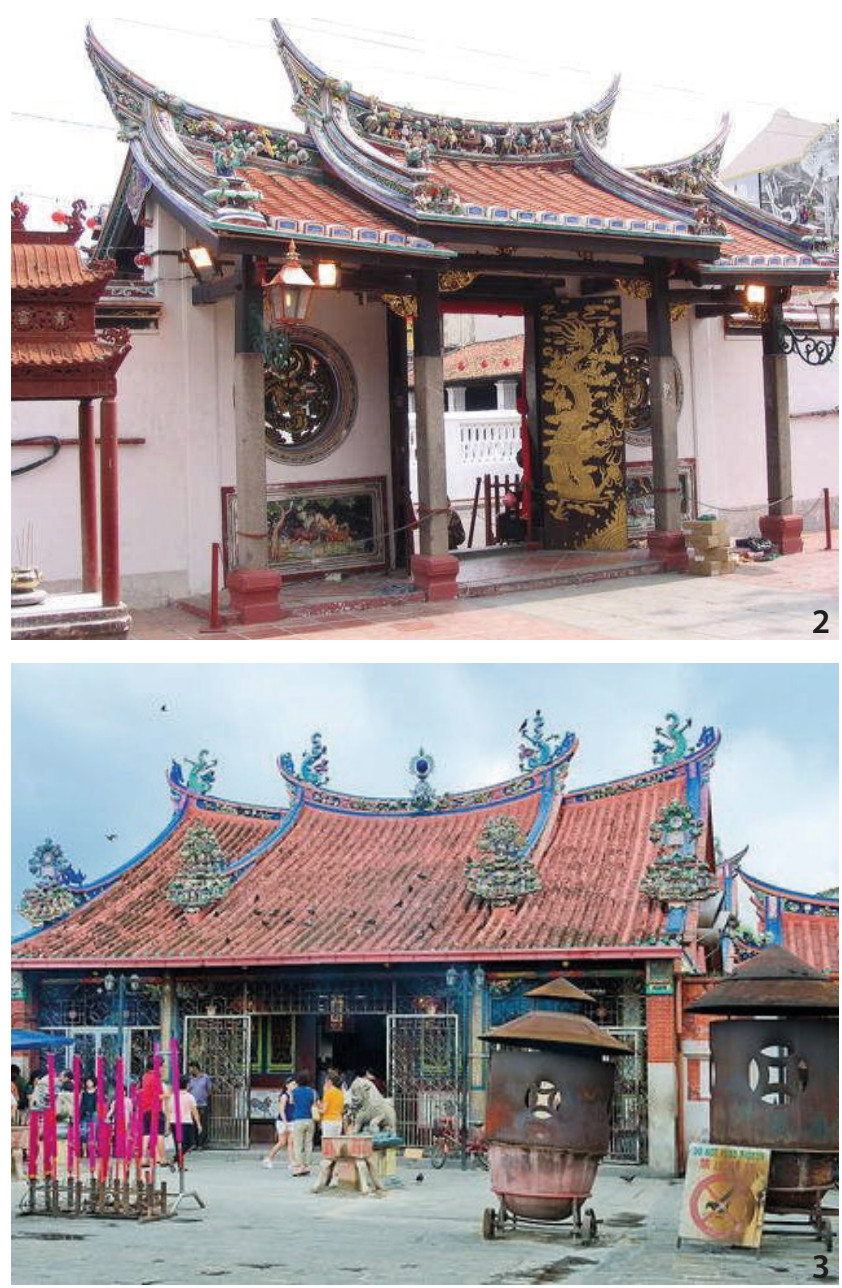

Many have long assumed that Malaya had no urban system before its colonial-immigrant settlement. ${ }^{4}$ One of the most significant scholars studying the indigenous cities of Southeast Asia has stated that, 'the earliest cities originated as a result of the diffusion into the area of Chinese and Indian forms of political organisation and religion from the first century. Before this date, political power was scattered throughout the area in a series of tribal cells.' (McGee 1967, 29-41) With the diffusion of Indians, Muslims and Chinese into the area, two forms of settlements took shape. One of the earliest kinds of settlement was of the cult-centre form, based on religious beliefs such as Islam, Hinduism and Buddhism. In many settlements and cities, mosques, Indian temples and Chinese temples served as cores of the settlements. These organisations combined economic, political and social forces to make the earliest sacred cities come into being. ${ }^{5}$

The second kind of city that emerged in the Straits was a 'market city', based on trading ports, where the maritime route was the main power to control trade. Based on such a foundation, these trading ports along the Malacca 

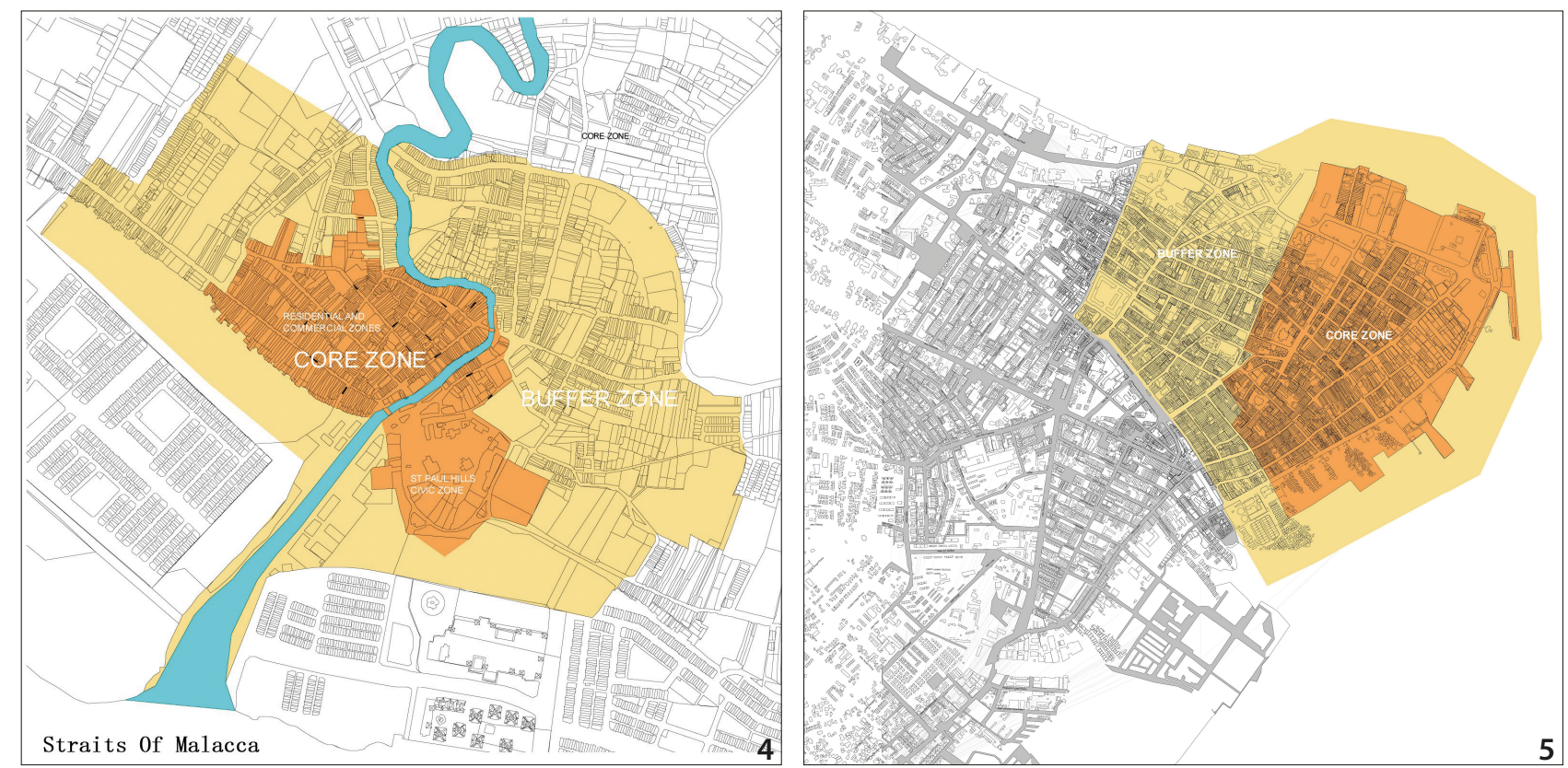

Figure 4 World Heritage Map of Malacca City: Core Zone and Buffer Zone (Source: the author).

Figure 5 World Heritage Map of Penang City: Core Zone and Buffer Zone (Source: the author).

Straits, such as Malacca itself, began to flourish during the $14^{\text {th }}$ century. ${ }^{7}$ However, some scholars doubt whether these cult-centres or trading ports can be thought of as the earliest cities. For example, Michael D. Coe doubts whether the surpluses were regarded as a tribute to the cult centres:

A surplus (which was regarded as a tribute to the early cult-centres) is surely the precondition of civilization, for lacking it a society cannot support the non-food producing specialists (like priests and artisans) who are the creators of civilization. As already mentioned, what matter is what becomes of this surplus. In the urban organic civilisations it is consumed by the cities; in the non-urban unilateral civilizations it is taken as a tribute for the support of cult centres (Coe 1961, 65-85).

Regarding the processes of primary urbanisation of Malaya before the $15^{\text {th }}$ century, Malaya was more akin to folk societies controlled by centralised social, religious and political power. The folk society was further urbanised through contact with peoples from different cultures. The main driving force in the processes of the evolution of the urban system was the result of European and Chinese colonisation, in Victor Purcell's (1948, vi) words, 'the joint creation of the British and Chinese enterprise. However, these processes seemed impossible without the force imposed upon the formation by the immigrant-mixed, traditional folk settlements. Within such an urban system framework that combined religious and trading factors together, the following sections will show the pioneer settlements respectively that later became primary cities: Malacca and Penang (Figure 4, Figure 5).

\section{Chinese Architectural Heritage in Malacca and Penang}

The discovery of the route from Europe to the East through the Cape of Good Hope in the late $15^{\text {th }}$ century changed Malacca's history. The silks, spices and wealth of the East roused the crusading and adventurous Portuguese to venture first to Goa, then to the Straits of Malacca and beyond (RCM 1984). The Portuguese took possession of Malacca in 1511, occupied St. Paul's hill and built a town surrounded by walls measuring 20 feet high and 5 feet thick. Within the town, various administrative buildings were built. Since then, Islam was replaced by Christianity, which became the major official religion in Malacca.

Portugal's capture of Malacca began the history of the expansion of three European powers in the Malacca Straits: Portugal, Netherlands and Great Britain. However, these colonial conquests did not bring major changes to the main structure of the society. ${ }^{8}$ After the Portuguese were expelled in 1641, the Dutch took their place. The Dutch immediately began to repair the fortifications left 
by the Portuguese, and to arrange for permanent occupation of the city. Timber and carpenters were procured from Acheen. The Chinese from Batavia showed that some of the Chinese settlers came to Malacca not directly from China, but instead from elsewhere in the region, which had unofficial contact with China earlier than Malacca. The Dutch remained until 1795 when the British attacked it, and succeeded to power, which they retained until 1818 when, by agreement, the Dutch returned. Finally, by a treaty with Holland in 1824, Malacca became British again (Macmillan 1923).

However, neither the Portuguese nor the Dutch periods changed the mixed pattern of the social structure. The initial economy of Malacca was established through trades among various ethnic groups. Different ethnic groups were still located in their own districts, in Malay language, Kampongs, such as the Indians located in Kampong Kling, the Chinese in Kampong China, etc. From the map, the Chinese village (Campon China) or the Chinese communities in the city are faintly visible. Besides the function of trade, different religions also shaped the internal pattern of the city, the social structure, and the patterns of administration.

At the northern part of the Malacca Straits, old PingLang-Yu existed for over 500 years on the Malay Peninsula. It had been a trading region and its river mouths had been used by shipping from India. It also attracted traders from Sumatra and the west coast of the Malay Peninsula. The occupation of this almost uninhabited island and the setting up of the British trading post by Captain Francis Light in 1786 made it the first trade base and the Malaya headquarters of the English East India Company, as well as the first British colonial settlement in the Malay Peninsula (Andaya and Andaya, 1982; Macmillan 1923). The small township which Light had laid out as the commercial town bounded by Light Street, Beach Street, Chulia Street and Pitt Street, was named 'George Town'. A difference between George Town and Penang exists in scales.

When Penang was founded, the only people on the island were a few fishermen. The earliest inhabitants were mainly Malay and those who accompanied the Europeans from India. Hardly a year after the founding of the settlement, there were already shops in the bazaar kept by Chinese immigrants (Lim 1978). In 1788, only two years after the founding of Penang, the Chinese formed two-fifths of the total population of about one hundred (Lim 1978). They worked as carpenters, smiths, traders, shopkeepers and planters; the Indians were shopkeepers or labourers and Malays worked largely as farmers. The town lines laid out by Francis Light assigned localities to the various nationalities. Since then, the population became more mixed: British, Dutch, Portuguese, Armenians, Arabs, Chinese, Indians, Malays, Burmese, Siamese, Javanese, etc. In Francis Light's time, many of the Chinese came from Malacca or directly from China through the Malacca Straits.

The early structure of Chinese settlement in the city, much like that of the villages in southern China, might have been taken unconsciously from the early Chinese pioneers who had their buildings with their local shrine and cult. When the Chinese first immigrated to this new land, what they could bring with them were only the habits, the folk traditions, the system and the memory of their hometown and ancestors, which provided the strong social foundation for the temples, huiguans and shop-houses built afterwards.

Within the structure of the Chinese community and the Chinese settlement, temples, huiguans and shop-houses first took the forms of their prototypes that originated in their hometowns in South China. Based on subculture traditions, these buildings are different from each other in their facades, construction details and decorations seen as 'Fujian style, 'Guangdong style' and 'Zhejiang style'. On the other hand, these temples, huiguans and shop-houses were influenced by Indian, Moslem, Malay and European styles and details. They also adapted to the settlements' contexts and social settings. They co-existed in cities with other types of architecture such as shop-houses (Figure 6).

\section{Temples as Chinese Architectural Heritage}

Temples built at the early time of Nanyang were a kind of building made of atap, thatch and wood. The physical ruins of these early temples couldn't be found, due to the perishable nature of building construction materials.

\section{Cheng Hoon Teng}

Malacca's Cheng Hoon Teng is reputedly the earliest Chinese temple in the Chinese settlement in the Malacca Straits. Cheng Hoon Teng is the Fujian name of the temple. According to the stone tablets left in the temple, Cheng Hoon Teng was believed to be founded from 1645 to 1673 by the First Captain Zheng Fangyang (Tay Hong Yong) (Hoyt 1993) ${ }^{9}$. The building was built in 1704 by Captain Zheng Qilu (Chan Ki Lock). ${ }^{10}$ In 1801, Cheng Hoon Teng temple was reconstructed by the Eighth Captain well-known as a great leader, Chai Shizhang (Chua Su Cheong), who came from Zhangzhou in $1765^{11}$. There 


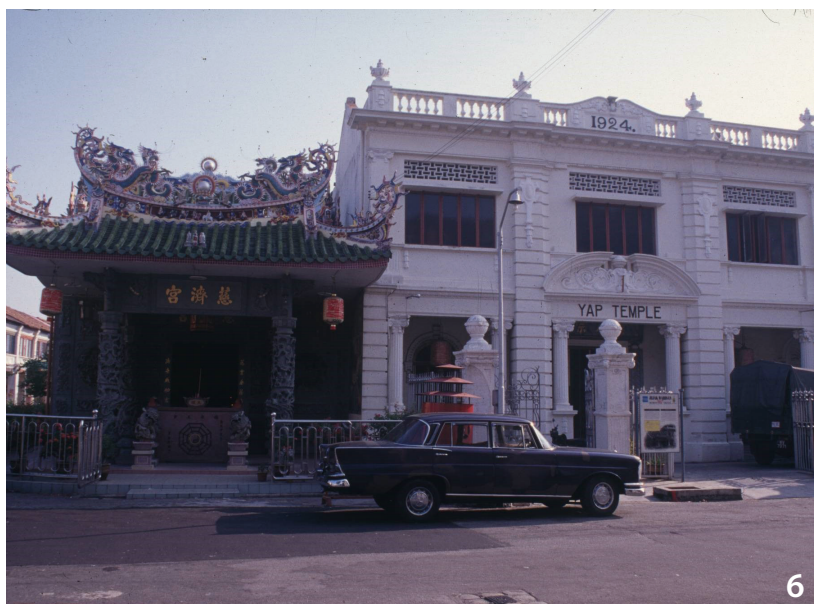

Figure 6 Community temple and Yap clan temple in Penang (Source: the author).

were various minor repairs and additions to Cheng Hoon Teng buildings. ${ }^{12}$

Cheng Hoon Teng Temple is situated on one of the streets of Malacca's historic city centre. The street was named after it as 'Temple Street'. The temple complex occupies an area of 49,510 sq. ft., and was carefully laid out with a view of the river, oriented toward China. Following the form of the Chinese temple, the spatial sequence is from front to back, and from the main altar building to the sides. The Guanyin Cheng Hoon Teng Temple is principally assigned to the worship of Guanyin, with the side portions of the hall on its right and left reserved respectively for Guandi, the God of War, as the patron Saint of tradesmen (in his role as the God of Wealth) and for Mazu, the Empress of Heaven, as the special guardian of sailors, fishermen and voyagers on the high seas (Mei 2000).

\section{Guang Fu Gong}

Guang Fu Gong is locally called Guanyin Teng. Besides serving as a temple, it was also a community headquarters for the Cantonese and Fujianese until the Ping Zhang Huiguan in Penang replaced such function. It was founded in 1800 on a piece of land donated in perpetuity by the East India Company Government during the administration of Sir George Leith. ${ }^{13}$ Before Francis Light anchored in Penang, there had already been a Chinese settlement and two temples in Penang. One was Guang Fu Gong Temple.

Orientated along the east-west direction, Guang $\mathrm{Fu}$ Gong Temple was built on a piece of ground on Pitt Street. It was erected, according to the stone tablet outside the temple, in 1800 and enlarged by its the first major renovation in 1824 . The older part consists of a hall of 40 sq. ft. with a paved terrace in front, on which stand two lions and an urn in which holy paper is burnt. The front of the temple was decorated with painted carvings. The principal deity in the main hall is Guanyin, and the secondary deities are Tianhou on the left and Xietian Dadi on the right. In the front of the house, an opening of about 5 sq. ft. is left from which the gods command a view of China Street. The temple was recognised popularly as a building located at the sites according to the Chinese idea about feng shui to face the street directly through the sea to block the qi (spiritual energy) from the sea. Similarly, the Chinese endeavoured to buy the ground along Beach Street facing the temple, to keep it free of buildings. Between the old and the new hall is an open, paved courtyard. The new hall was supposed to be enlarged to contain images of the other gods worshipped on certain days. The hall contains lanterns, altars, urns, candlesticks, etc. On the back of the hall, one of their deified philosophers was sketched, attended by seven or eight worshippers as well as symbols similar to those used in the temple. The temple was built as a replica of Cheng Hoon Teng of Malacca. The temple complex consists of two parts. The plan of the temple complex is based on the courtyard system. The left part of the temple complex includes the front hall, the courtyard and the back hall. The right part of the temple complex includes the living quarter for monks. The front hall of the temple complex was completed in 1800, while the back hall and the right part of the temple complex were completed 30 years later. The courtyard connects two halls in a veranda with a vaulted roof. The first major renovation and redecoration of Guang Fu Gong Temple was carried out in 1824 . $^{14}$ A new hall was built at the back of the main hall on a piece of ground donated by the heir of Captain China. A living quarter for the resident monks was added at the east side of the main temple. New deities were enshrined in the new hall to meet the requirements of the various prefectures of the Chinese community. In 1833, the Straits Settlements Government appointed a three-man committee to ascertain the total area of land owned by the temple, and an E.I. grant numbered 2420 was issued by the Straits Government in 1838 indicating that the piece of land which contained an area of 24,169 sq. ft. with the temple erected thereon was a perpetual property of the Chinese community for religious functions.

With both Guanyin and Mazu as common objects of communal and individual worship in return for wealth and health, the temple served as the spiritual protector 
of the immigrant Chinese in a new alienated environment, where popular local deities of Fujian and Guangdong enjoyed the active worship as symbols of communal unity and intangible links between the devotees and their homelands. Ethic-political cults of deified men and sages served the social function of encouraging local Chinese to practice civic morals of loyalty, bravery, righteousness and humanness, besides being exemplary figures of human behaviour. Since 1888, the Fujianese representatives in Guang Fu Gong were nominated by five big surnames Kongsis: Lim Kongsi, Khoo Kongsi, Yeoh Kongsi, Tan Kongsi and Cheah Kongsi. Besides the religious function, Guang Fu Gong also played an active role in the social life of Chinese in Penang. Like other Fujianese Kongsi in Penang, Guang Fu Gong held elaborate rituals in the 1850s to mark the birthdays of Guanyin and Mazu. Ceremonies were also conducted on Chinese festivals. Hundreds of thousands of Chinese thronged the temple in the thick fog of incense and fire crackers either to offer prayers or to see the public theatrical performance. These activities alerted the attention of the government of that time. Official restrictive measures were adapted to the mode of communal worship and related activities. The confrontation between Chinese community and the authority broke out in the front courtyard of Guang Fu Gong on 14 March 1857 which result in the partial destruction of the temple, weakening the religious function of the temple and deteriorating the institutional links between Fujianese and Cantonese. Under such a situation, some Chinese leaders reconsidered the possibility of the Chinese community existing as a unified community rather than as separate sections based on dialects or territories. In 1862, the Board of Directors comprised of representatives of the five big surnames: Lim, Khoo, Yeoh, Cheah and Tan from Fujian, and Huang, Mei, Feng, Lin from Canton, discussed the issue of major restoration works of the temple. Reconstruction work was completed in a year. The newly renovated Guang Fu Gong again stood on the same site as the centre of religious activities as well as organisation dealing with bang (gang) fights and sub-groups of Chinese community affairs. Until 1881, the establishment of the Penang Chinese Town Hall ended the history of Guang Fu Gong as the central organisation of all Chinese in Penang. ${ }^{15}$ Since then, the temple has only functioned as a religious centre in the city.

\section{Huiguans and Shop-houses}

Between southern China and the Malacca Straits, trade was another foundation on which huiguans were established. Huiguans served as bases for sojourners to maintain their connections with each other in aboriginal places and served as links with their native lands. Huiguan buildings provided the immigrants with a public place to gather, to discuss issues within the community, and to repose their memories to their ancestors. It was also a place for merchants to conduct business and commercial exchange, which played a vital and multi-faceted role in establishing relations with China.

The prosperity of huiguan along the southeast coast (Fujian and Guangdong) developed mainly after 1840 because of the Nanjing Treaty with the British. Before 1840, as a trading network centre of southern Fujian, several kinds of hang in Xiamen represented the commercial character of this coastal city. Hang implies 'trade' more often than 'guild' (Yang 1970). In the case of maritime southern Fujian, the word hang means simply an authorised firm. Some of the Fujianese sea-merchants in Ming times were appointed by the government to manage the foreign trade. They were called 'shopkeepers' in Haicheng, the centre of maritime southern Fujian (Fu 1956). Such kinds of hangs were based on the family business in Ming Fujian. Once a family started a business and was accepted as authorised shopkeepers, its name would be recorded in the shopkeeper-household register. Such status would hold generation after generation and these hangs households were required to supply the local yamen with all kinds of necessities. Many hang households played important roles within the network of maritime business and trade of Nanyang. Those hangs dealing with foreign goods were called Yanghuo Hang which were both exporters of native products to Nanyang and importers of foreign goods for domestic trade. Such Yanghuo Hang was the prototype of the commercial huiguan, which controlled both coastal and overseas trade (Fu 1956). These huiguans had an architectural expression similar to shop-houses.

Chinese immigrants settled mainly south of the Malacca River. They became small shopkeepers or artisans in both rural and urban areas. They built terrace houses and shop-houses in town and their settlement was mainly along the Malacca River which was focused on trade and the earliest part of the old Malacca city. Their neighbourhoods, urban and uniform, contrast sharply with the traditional Malay kampongs. The houses faced the main street of Malacca with their backs to the shore. The space between the road and sea was so narrow that the Chinese had to build out over the water. From the Malacca River to the northern end of the town, every house on the seaside of the long main street had one foot on land and one in 

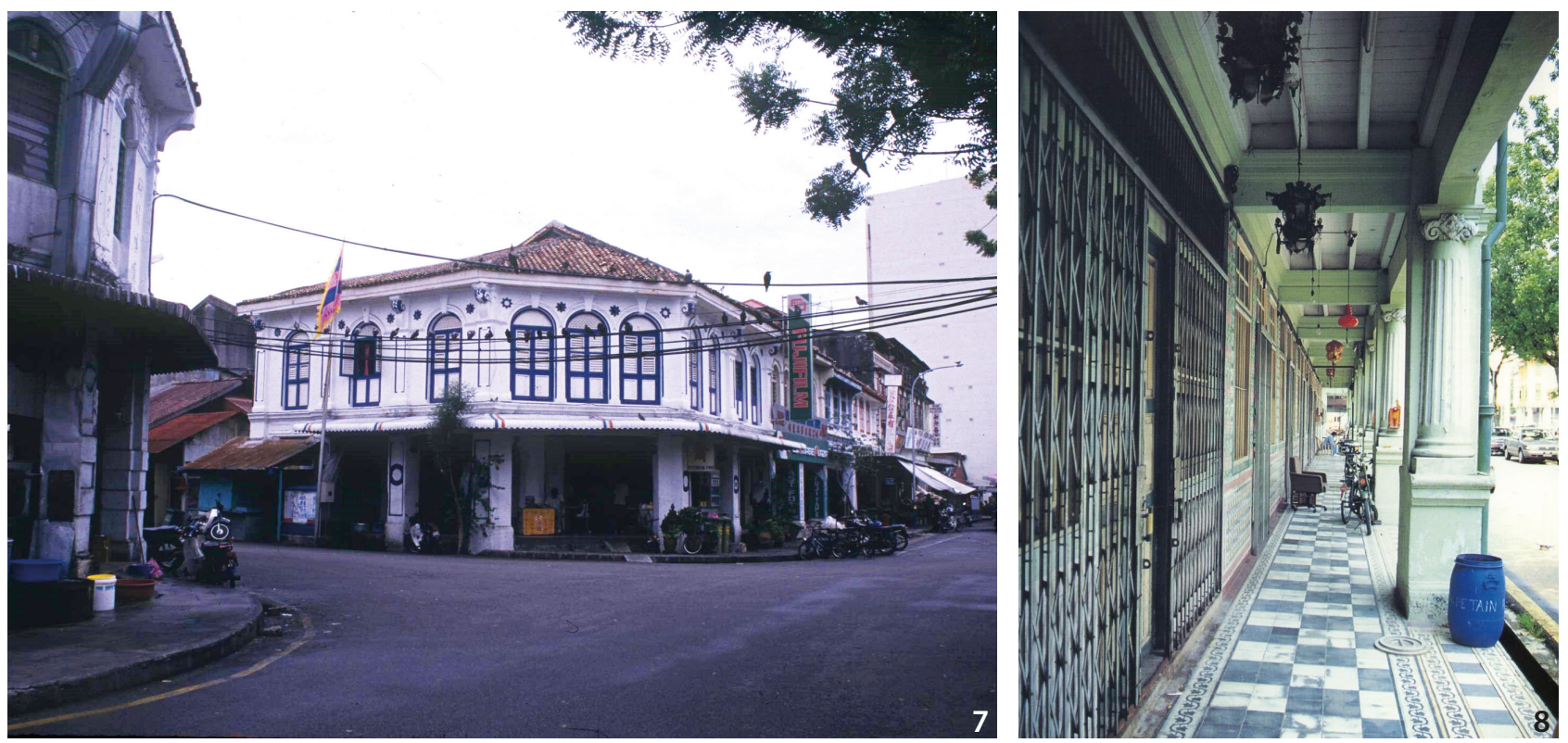

Figure 7 Community temple and Yap clan temple in Penang (Source: the author).

Figure 8 The 'five-foot way' as the urban fabric (Source: the author).

the sea, which made the town with its legs in the sea. The main activity of these early Chinese was trade and their main types of buildings were houses and shop-houses.

Several types of huiguan established by the immigrants appeared in the Malacca Straits around the late $18^{\text {th }}$ and early $19^{\text {th }}$ centuries-the heyday of the junk trade between southeast China and Nanyang. Functionally, huiguans in the Malacca Straits can be divided into four types according to their social structure and function: KinshipSurname huiguan; Dialect huiguan; Territory huiguan; Occupation huiguan. Besides the family itself, the social organisation based on native place, lineage, and common mercantile interest was the most distinctive aspect of Nanyang Chinese society. The architectural changes of huiguans were expressed in the changes from hangs for merchants' trading and living to buildings functioning as shop-houses. The buildings were expressed in a shophouse style, which was transplanted from southern China’s hang prototype. Such kinds of huiguan function more on trade than other social roles.

Most of the shop-houses were partially used for commercial purposes, whereby the front room of the ground floor was given over for these purposes, and the veranda that extended into the street was also devoted to commerce. These structures also served residential functions, whereby the rooms and spaces on the first floor - beyond the shop-were for family uses, as were the second or third floors of the buildings. Inside, for lighting and ventilation purposes, there were often a series of 'sky wells' (tianjing, in Chinese) that extended back from the street, since many lots were extremely narrow and deep. Most of the shop-houses had narrow facades characterised either by European classical stylistic details (elaborately plastered onto the brick structure to simulate stone), or by distinctive Chinese roofs and curved eaves, which identified them as being reminiscent of a Chinese cityscape. Some materials and motifs were imported from China. Shop-houses were so prevalent as a building type that they shaped the basic form and building character of the city. The entrance of the shop houses was marked by a fivefoot wide arcade, that commonly known as a 'five-foot way' (Figure 7, Figure 8).

\section{Conclusion: Constructing the Meaning of Chinese Architectural Heritage}

From temples to huiguans and shop-houses, the study expressed the meaning of vernacular Chinese architecture that responded to the local multi-cultural, multi-religious society in a more complex way. Temples were located at chosen sites, responding to the local interpretation of the Chinese feng shui. Such an idea was less about a religious concept of space, but about respect to the Chinese ideas about natural geography. A Chinese temple represents society more than religion. Previously mentioned temples that were established and built by Chinese immigrants represented their religious feeling-a sense of belongingbut not every aspect of Chinese social lives, such as trade 
and commercial aspects. Under such condition, another type of architecture-huiguan-overlaps with temple in regard to religious function, but differs from the former in regard to other social functions. On the multi-functional ground of a city, architecture composes impression and atmosphere paralleled with city history as an art of human habit and an art of coherent three-dimensional composition, e.g., enclosures, connections, landmarks and views. All elements are woven together to form a coherent relationship and a place with physical boundary and spiritual atmosphere.

After the establishment of Captain System and the completion of Chinese architecture, the Chinese community was more like a united whole. From this sense, architectural heritage existed as a core organisation of Chinese community in Malacca. As an expression of people's social and cultural backgrounds, architecture can be a palpable symbol of cultural identity. Malacca straits have its early Indian influence, Chinese influence, Portuguese influence, Dutch influence, and British influence. In every period of Malacca history, cultural marks were left which can be found in Malacca architecture. There, the Chinese built important public buildings such as temples, huiguans and shop-houses to express their identity, but also liked to live with the Western-style architecture to express their economic status in the society after they became rich. This created a complex built environment in which wealthy Chinese preferred to live in villas or mansions while their true identity was embodied by public buildings designed with traditional Chinese-style architecture.

Temples, huiguans and shop-houses have existed as Chinese architectural heritage for over 300 years. From the beginning of their existence, they didn't have the meanings we interpret today. It is not a building's special architectural form or style that gives it monumental meaning and importance, but emotion stimulated by its presence, significant historical narrative, or the debated interpretation of historical facts.

Regarding the functions of temples, huiguans and shophouses, spiritually they represent the Chinese identity and popular religious meaning, while physically they not only provide space for religious practice, but also social and living space.

\section{Notes}

1. Nanyang, the literal rendering of which is 'Southern Ocean', is the older Chinese concept referred the 'southern' region to be reached by sea and the term for what we now call Southeast Asia. But 'Nanyang' used to mean the region immediately to the south of China, which includes the Philippines, the Dutch East Indies, Malaya and Borneo, Siam, Indochina, Burma, and sometimes even Ceylon and India. While another definition regarding this term was used both for the coastal provinces of southeast China, including Guangdong and Fujian. But when one speaks of the Nanyang Chinese today, one has in mind Chinese settled in Malaysia, Singapore, the Philippines and Indonesia-places reached by sea, in other words, specifically the South China Sea. See Lynn Pan, ed., The Encyclopaedia of the Chinese Overseas (Singapore: Archipelago Press, 1998), and Benedict Anderson, The Spectre of Comparisons: Nationalism, Southeast Asia and the World (London: Verso, 1998).

2. Cultural geography is the study of spatial variations among cultural groups and the spatial functioning of society. It focuses on describing and analysing the ways language, religion, economy, government, and other cultural phenomena vary or remain constant from one place to another. See Dohrs and Sommers, Cultural Geography: Selected Readings (McGill-Queen's University Press, 1967).

3. To deal with architecture as studied from an anthropological perspective, buildings exist as a representation of the culture of its inhabitants. See K.G. Lzikowitz, P. Sorensen, ed., The House in East and Southeast Asia: Anthropological and Architectural Aspects (London: Curzon Press, 1982), 173-180.

4. For this issue, see Lim Heng Kow, The Evolution of the Urban System in Malaya (Kuala Lumpur: Penerbit University Malaya, 1978).

5. The sacred cities were administrative, military and cultural centres of empires that drew their power from the tribute of conquered territories, and the labour supplies which could be manipulated by the rulers. The sacred city's plan was a reflection of the cosmological beliefs of the ruler, such as Angkor of old Cambodia and old Beijing. However, no neat pattern existed. T. G. McGee, The Southeast Asian City: A Social Geography of the Primate Cities of Southeast Asia (London: G. Bell and Sons, Ltd, 1967), 36.

6. In the market cities, the wealth came from the royal authorities' use of maritime power to ensure their control of trade, or their granting of privileges to foreigners to use their city as a trading port. The population of such cities was cosmopolitan and fluctuated in size in response to the city states' control of trade, such as Malacca. T.G. McGee, The Southeast Asian City: A 
Social Geography of the Primate Cities of Southeast Asia (London: G. Bell and Sons, Ltd, 1967), 32.

7. During the early centuries of the Christian era, there existed a Kingdom as Funan on the Indo-China peninsula, the trade at that period was conducted cross the land rather than through the Malacca Straits. With the decline of Funan and the political power shifting to the South, the land routes were replaced by sea-route trade. Before the rise of Malacca, Kedah, was regarded as the largest trading port along the Straits on the Peninsula on the basis of archaeological evidence from the fifth and sixth century. Paul Wheatley, The Golden Khersonese: Studies in the Historical Geography of the Malay Peninsula Before A.D. 1500 (Kuala Lumpur, University of Malaya Press, 1961), 326.

8. The capture of Malacca by the Portuguese in $1511 \mathrm{did}$ not bring about many changes in the structure of the society. The morphology and the character of the city depended a great deal on the function of the settlement, using the European elements such as the garrison towns within the fort area. This can be found in the Malacca city. See T. G. McGee, The Southeast Asian City: A Social Geography of the Primate Cities of Southeast Asia (London: G. Bell and Sons, Ltd, 1967), 49.

9. The man who was appointed as the head to take charge of the Chinese community during the Portuguese and Dutch period and such a system was demolished since British period of Malacca history. He was a Zhangzhou Hokien and had been called 'the Founder of the Chinese Colony in Malacca' after the similar style of the first Chinese Captain Soo Bencon in Batavia. Malacca Historical Society, Historical Guide of Malacca (Malacca: Malacca Historical Society, 1936), 81.

10. He was a native of Xiamen and son-in-law of Li Junchang. There is still a wooden board in that hall dated to 1705 , inscribed with four Chinese characters meaning 'This Ancient Relic of the Cheng Hoon-the Bright Clouds', said to be of his penmanship. In 1704 he built the main temple hall of the Cheng Hoon Teng where Guan Yin was enshrined.

11. 'Ma Liu Jia Di Ba Ren Hua Ren Jia Bi Dan-Chai Shi Zhang. Chuan Jia Zhi Bao (Malacca: Malacca Bao Shan Teng), 86. He also built the Bao San Teng Temple (Po Swa Teng) at the foot of Bukit China in 1795. Cheng Hoon Teng and Bao Shan Teng are two important temples for Chinese in Malaysia to look for their Chinese roots. It is significant to note that nearly all of the figures mentioned above were Hokiens Chinese Captain who had contributed much to the establishment and the construction of Cheng Hoon Teng temple. It was built by means of collecting money from local Chinese after they had their own community and their own headquarters in the society. The deities worshipped were San Bao Gong in the centre, Captain Chua in the right and Tianhou in the left.

12. Malacca Historical Society, Historical Guide of Malacca (Malacca: Malacca Historical Society, 1936), 82. After the first renovation by Chai Shi-zhang, the temple was again renovated in 1845 by Xue Fuji (Seet Hood Kee), a famous Teng Zhu. After the permanent occupation of Malacca by the British in 1824 the office of Captain China was abolished. To replace this functionary the Malacca Chinese resorted to the plan of creating the dignity of Teng Zhu, i.e. President of the Cheng Hoon Teng, which was tantamount to being the head of the Chinese community of the Settlement. They were appointed by the Chinese in Malacca, having the power of a Captain though not recognised by the government of the day when British controlled Malacca. A Teng Zhu held office during his life-time and commanded high moral authority and prestige among the Chinese in Malacca. He was looked upon as the community's first leader, whose opinions and decisions were respected by the people.

13. In the early $19^{\text {th }}$ century Penang as colonial frontier settlement, there was a discontinuity of traditional outgrowth of Chinese sub-culture and religious belief in an emerging enclave economy. After Dutch, Malacca was temporarily brought under the British jurisdiction thereby paving a way to an exodus of Malaccan Chinese traders, sea-faring men and labourers to Penang. Necessitated by 'mutual economic needs and cultural predilections, the Fujianese and Cantonese of Malacca and Penang jointly founded Guang Fu Gong with an initial sum of $\$ 3,700$. With Guanyin as the main goddess of worship and Mazu as an associate deity, the temple became a spiritual sanctuary of Fujianese and Cantonese on the island.

14. At that year, a sum of money was raised among Fujianese directors, including the Teng Zhus of Cheng Hoon Teng in Malacca, and other community heads in Penang and Singapore.

15. The Penang Chinese Town Hall was established in 1875 by virtue of a Trust Deed executed by the Officer Administering the Government of the Straits Settlement of Penang. The Trust Deed settled a plot of land situated at Pitt Street, Penang containing an area of 24,611 sq. ft. for the purpose of erecting a building 
which shall be known as the 'Penang Chinese Town Hall ' to serve as a civic centre for promoting the welfare of all classes of Chinese residing in the State of Penang. The objects of the Chinese Town Hall are to bring up for discussion any subject of importance and interest to the Chinese Community; to afford facilities for addresses, lectures, or debates; to provide a place for dramatic purposes; to receive or entertain distinguished personages; to settle any dispute or difference that may arise between members of the Chinese Community, if so desired; to do any other thing if it considers proper.

\section{Acknowledgement}

The author of this paper has been granted by the Chinese University of Hong Kong, and Tongji University of Shanghai, for the project 'Maritime Silk Road,1996-2016.' It has been presented at the conference 'Conservation of the Built Environment: ASEAN Perspective-_ICOMOS Thailand International Conference 2016'

\section{References}

Andaya, B.W., and L.Y. Andaya. 1982. A History of Malaysia. Macmillan Press Ltd.

Benedict, Anderson. 1998. The Spectre of Comparisons: Nationalism, Southeast Asia and the World. London: Verso.

Coe, M.D. 1961. "Social Typology and Tropical Forest Civilizations." Comparative Studies in Society and History 4 (1): 65-85.

Dohrs and Sommers. 1967. Cultural Geography: Selected Readings. McGill-Queen's University Press.

Fu, I-ling. 1956. Mingqing Shidai Shangren ji Shangye Ziben [Merchants in Ming and Qing Dynasty and Commercial Capitals]. Beijing: People's Publishing House.

Hoyt, Sarnia, Hayes. 1993. Old Malacca. Oxford University Press.

Lim, Heng, Kow. 1978. The Evolution of the Urban System in Malaya. Kuala Lumpur: Penerbit University Malaya.

Lynn, Pan, ed. 1998. The Encyclopaedia of the Chinese Overseas. Singapore: Archipelago Press.

Lzikowitz, K.G., and Sorensen, P., ed. 1982. The House in East and Southeast Asia: Anthropological and Architectural Aspects. London: Curzon Press.

Macmillan, Allister, eds. 1923. Seaports of the Far East. Reprint. Originally published: London: W. H.\& L. Collingridge.

Malacca Historical Society. 1936. Historical Guide of
Malacca. Malacca: Malacca Historical Society.

McGee, T. G. 1967. The Southeast Asian City: A Social Geography of the Primate Cities of Southeast Asia. London: G. Bell and Sons, Ltd.

Purcell, Victor. 1948. The Chinese in Malaya. Singapore: Oxford University Press.

RCM (Rotary Club of Malacca). 1984. The Illustrated Historical Guide to Malacca. Malacca: A Rotary Club of Malacca Community Service Project.

Wheatley, Paul. 1961. The Golden Khersonese: Studies in the Historical Geography of the Malay Peninsula before A.D. 1500. Kuala Lumpur, University of Malaya Press, 1961.

Yang, Lien-sheng. 1970. "Government Control of Urban Merchants in Traditional China." Tsing-hua Journal of Chinese Studies, new series, 8: 1-2. 